The National Bureau of Standards ${ }^{1}$ was established by an act of Congress March 3, 1901. The Bureau's overall goal is to strengthen and advance the Nation's science and technology and facilitate their effective application for public benefit. To this end, the Bureau conducts research and provides: (1) a basis for the Nation's physical measurement system, (2) scientific and technological services for industry and government. (3) a technical basis for equity in trade. and (4) technical services to promote public safety. The Bureau consists of the Institute for Basic Standards, the Institute for Materials Research, the Institute for Applied Technology, the Institute for Computer Sciences and Technology, and the Office for Information Programs.

THE INSTITUTE FOR BASIC STANDARDS provides the central basis within the United States of a complete and consistent system of physical measurement; coordinates that system with measurement systems of other nations; and furnishes essential services leading to accurate and uniform physical measurements throughout the Nation's scientific community, industry; and commerce. The Institute consists of a Center for Radiation Research, an Office of Measurement Services and the following divisions:

Applied Mathematics - Electricity - Mechanics - Heat - Optical Physics — Nuclear Sciences ${ }^{2}$ - Applied Radiation ${ }^{2}$ - Quantum Electronics ${ }^{3}$ - Electromagnetics ${ }^{3}$ — Time and Frequency " L Laboratory Astrophysics" - Cryogenics ".

THE INSTITUTE FOR MATERIALS RESEARCH conducts materials research leading to improved methods of measurement, standards, and data on the properties of well-characterized materials needed by industry, commerce, educational institutions, and Government; provides advisory and research services to other Government agencies; and develops, produces, and distributes standard reference materials. The Institute consists of the Office of Standard Reference Materials and the following divisions:

Analytical Chemistry - Polymers - Metallurgy — Inorganic Materials — Reactor Radiation - Physical Chemistry.

THE INSTITUTE FOR APPLIED TECHNOLOGY provides technical services to promote the use of available technology and to facilitate technological innovation in industry and Government; cooperates with public and private organizations leading to the development of technological standards (including mandatory safety standards), codes and methods of test; and provides technical advice and services to Government agencies upon request. The Institute consists of a Center for Building Technology and the following divisions and offices:

Engineering and Product Standards - Weights and Measures - Invention and Innovation - Product Evaluation Technology - Electronic Technology - Technical Analysis - Measurement Engineering - Structures, Materials, and Life Safety ${ }^{4}$ — Building Environment " - Technical Evaluation and Application ${ }^{4}$ — Fire Technology.

THE INSTITUTE FOR COMPUTER SCIENCES AND TECHNOLOGY conducts research and provides technical services designed to aid Government agericies in improving cost effectiveness in the conduct of their programs through the selection, acquisition, and effective utilization of automatic data processing equipment; and serves as the principal focus within the executive branch for the development of Federal standards for automatic data processing equipment, techniques, and computer languages. The Institute consists of the following divisions:

Computer Services - Systems and Software - Computer Systems Engineering - Information Technology.

THE OFFICE FOR INFORMATION PROGRAMS promotes optimum dissemination and accessibility of scientific information generated within NBS and other agencies of the Federal Government; promotes the development of the National Standard Reference Data System and a system of information analysis centers dealing with the broader aspects of the National Measurement System; provides appropriate services to ensure that the NBS staff has optimum accessibility to the scientific information of the world. The Office consists of the following organizational units:

Office of Standard Reference Data — Office of Information Activities - Office of Technical Publications - Library - Office of International Relations.

\footnotetext{
${ }^{1}$ Headquarters and Laboratories at Gaithersburg, Maryland, unless otherwise noted; mailing address Washington, D.C. 20234.

${ }^{3}$ Part of the Center for Radiation Research.

${ }^{3}$ Located at Boulder. Colorado 80302.

4 Part of the Center for Building Technology.
} 


\section{Photometric Data Variability of Automotive Lighting Components}

Bert G. Simson

National Highway Traffic Safety Administration

Department of Transportation

Washington, D.C. 20590

and

John Mandel

Institute for Materials Research

National Bureau of Standards

Washington, D.C. 20234

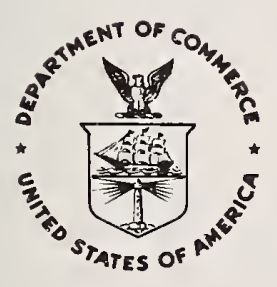

U.S. DEPARTMENT OF COMMERCE, Frederick B. Dent, Secretary

NATIONAL BUREAU OF STANDARDS, Richard W. Roberts, Director

Issued March 1974 


\section{National Bureau of Standards Technical Note 821}

Nat. Bur. Stand. (U.S.), Tech. Note 821, 15 pages (Mar. 1974)

CODEN: NBTNAE 
Photometric Data Variability of Automotive Lighting Components

Bert G.. Simson and John Mandel

Four automotive lighting components were tested in three commercial testing laboratories to estimate the degree of photometric data repeatability and reproducibility. The laboratories used the photometric testing techniques required by Federal Motor Vehicle Safety Standard No. 108. The precision of this test method was placed in a range of about 10 percent coefficient of variation. However, this value should be considered more as an indication of existing conditions than as a predictive parameter.

Key words: Federal Motor Vehicles Safety Standards; interlaboratory test evaluation; motor vehicles; photometric testing; safety standards.

\section{Introduction}

FMVSS No. 108 [1] ${ }^{1}$ specifies minimum performance requirements for automotive lighting components such as tail lamps, stop lights, reflex reflectors, sealed beam headlights, etc. Requirements in the standard include detailed procedures for various mechanical, environmental and photometric tests. This paper discusses a round robin experiment designed to estimate the degree of photometric data repeatability for identical lighting components within a single laboratory, and the reproducibility among several laboratories. The sample consisted of two parking and two tail lamps representing three lighting component manufacturers. The components had previously been selected from automotive assembly lines for compliance testing of the Office of Standards Enforcement (OSE) [2].

\section{Test Procedure}

In practice, the photometric tests were conducted as follows: A lighting component, (such as a tail lamp), was mounted unto a test fixture built to simulate the component's orientation in its designated vehicle. The original bulb was

Figures in brackets indicate the literature references at the end of this paper. 
replaced with another bulb calibrated 2 in accordance with techniques specified in the SAE Lighting Standard [3]. Then, the fixture with the lamp was mounted on a goniometer with two angular degrees of freedom. The goniometer could be indexed ten degrees of arc from the normal in the vertical, and twenty degrees of arc from the normal in the horizontal plane. A photoelectric detector, facing the assembly from 100 feet away, and the associated electronic equipment completed the experimental setup.

FMVSS No. 108 [1] requires the measurement of directiona 1 luminous intensity (in candlepower) at 27 defined horizontal and vertical angle combinations of the goniometer's setting. To check for compliance with the minimum requirement in the standard, the 27 candlepower values are pooled into seven groups representing aggregates of three to five test point values. Figure 1, FMVSS No. 108 [1] 1 ists minimum candlepower values for each group (also called "zone").

In this experiment, we tested four lamps in three 1 aboratories under contract with the OSE [2]. While it is generally advisable to run interlaboratory studies on no less than six, and preferably fifteen or more laboratories [4], it was impossible in this case to conform to these requirements. Indeed, the three participating laboratories are the only commercial institutions in the U.S. engaged in this type of testing. To provide data for the within laboratory variability, we tested each lamp four times in each laboratory, using different rated bulbs. The bulbs were operated at the designated mean spherical candlepower [3], and they were calibrated by each laboratory in an integrating sphere. The sixteen lamp-bulb combinations were tested in a random order in each laboratory, the order being different from laboratory to laboratory.

\section{Statistical Analysis of Data}

The data were first arranged in a two-way table, (Table 1), in which the rows represented the .12 1aboratory and bu $1 \mathrm{~b}$ combinations ( 3 laboratories $x 4$ bulbs), and the columns represented the 281 amp and zone combinations ( 4 1amps $x$ 7 zones). An analysis of this table of data showed no significant systematic differences between the four bulbs used in the experiment. Therefore, the four results obtained by each laboratory for a particular zone on a given lamp, using the four bulbs, were treated as replicate measurements. The statistical analysis then proceeded to the calculation of the repeatability and reproducibility [4] of the test method.

2 preceding the first calibration, the bulbs were seasoned for $1 \%$ of their rated average lifetime to assure stability. 
The standard deviation of repeatability, $s_{r}$, is a measure of the variability obtained when the same laboratory measures repeatedly the same zone of the same lamp, using, however, a different bulb for each replicate measurement.

The standard deviation of reproducibility, $S_{R}$, is a measure of the variability obtained between single measurements made in different laboratories on the same zone of the same lamp. The estimate, $S_{R}$, is obtained by the formula $s_{R}=\sqrt{s_{r}{ }^{2}+s_{L}{ }^{2}}$ where $s_{r}{ }^{2}$ is the square of the standard deviation of repeatability defined above, and $S_{L}{ }^{2}$ is the component of variance due to systematic differences between laboratories.

Table 2 ists, for each zone of each 1 amp, the average value over all laboratories and bulbs, as well as the standard deviation for repeatability and reproducibility, all expressed in units of candlepower. It should be noted that both $\mathrm{s}_{r}$ and $S_{R}$ vary between 1 amps and between zones, and a closer examination of the data reveals that both $s_{r}$ and $S_{R}$ increase as the magnitude of the measured value increases. Thus, the coefficient of variation will be a less variable quantity than the standard deviation for both repeatability and reproducibility. Table 3 is analogous to Table 2 , but lists the percent coefficients of variation (\%CV) instead of the standard deviations.

\section{Conclusion}

The average coefficients of variation of repeatability and reproducibility are 1 isted in Table 4 . It should be observed in the first place that the values relating to reproducibility $\left(v_{R}\right)$ suffer from the severe shortcoming of being based on only three laboratories. Therefore these values should be considered more as an indication of existing conditions than as predictive parameters. This being recognized, the values in Table 4 place the precision of this test method in a range of about 10 percent coefficient of variation. This information will undoubtedly be of value to members of the lighting equipment industry who wish to evaluate their equipment by this method. 
[1] Federal Motor Vehicle Safety Standard No. 108 Lamps, Reflective Devices and Associated Equipment-Passenger cars, Multipurpose Passenger Vehicles, Trucks, Buses, Trailers and motorcycles (Docket No.69-18). 35 F.R. 16842, Octover 31, 1970; 37 F.R. 21328, October 7, 1972; 37 F.R. 25235, November 29, 1972.

[2] Office of Standards Enforcement, Motor Vehicle Programs, National Highway Traffic Safety Administration, U.S. Department of Transportation.

[3] Society of Automotive Engineers (SAE) No. J575e, August, 1970 .

[4] Repeatability and Reproducibility, A simple analys is providing excellent parameters. Materials Research and Standards, Vo1. 11, No. 8, pp. 8-16, 1971 . 


\section{TABLE 1}

DIRECTIONAI LUMINOUS INTENSITY - CANDLEPONER

I.AMP NO. 1

\begin{tabular}{ccccccccc} 
Lab. & Bulb & $z-1$ & $z-2$ & $z-3$ & $z-4$ & $z-5$ & $z-6$ & $z-7$ \\
\hline 1 & 1 & 60.0 & 68.0 & 71.0 & 121.0 & 47.0 & 31.2 & 33.8 \\
& 2 & 51.9 & 67.0 & 71.0 & 133.0 & 53.0 & 33.01 & 39.7 \\
& 3 & 54.9 & 66.0 & 75.0 & 138.0 & 52.0 & 34.0 & 36.9 \\
& 4 & 56.6 & 63.0 & 70.0 & 122.0 & 48.0 & 31.8 & 33.4 \\
& & & & & & & & \\
& 1 & 59.0 & 74.2 & 75.5 & 139.6 & 57.0 & 34.7 & 43.1 \\
& 2 & 52.1 & 71.5 & 65.5 & 131.5 & 58.4 & 29.5 & 42.1 \\
& 3 & 56.8 & 72.8 & 75.7 & 143.4 & 57.5 & 34.2 & 41.5 \\
& 4 & 56.0 & 68.1 & 70.4 & 127.6 & 52.2 & 32.1 & 36.9
\end{tabular}

$\begin{array}{lllllllll}3 & 1 & 53.19 & 62.50 & 67.30 & 118.1 & 45.70 & 30.35 & 32.29\end{array}$

$\begin{array}{llllllll}2 & 49.19 & 63.30 & 67.50 & 121.1 & 49.10 & 30.61 & 37.43\end{array}$

$\begin{array}{llllllll}3 & 51.10 & 63.70 & 69.30 & 127.7 & 50.10 & 31.20 & 36.90\end{array}$

$\begin{array}{llllllll}4 & 59.48 & 61.80 & 66.50 & 117.2 & 50.10 & 30.92 & 38.83\end{array}$ 
TABLE I (continued)

IAMP NO. 2

\begin{tabular}{ccccccccc} 
Lab. Bulb & $Z-1$ & $Z-2$ & $Z-3$ & $Z-4$ & $Z-5$ & $Z-6$ & $Z-7$ \\
\hline 1 & 1 & 19.9 & 19.8 & 26.5 & 49.6 & 27.4 & 27.8 & 23.0 \\
& 2 & 19.1 & 20.5 & 21.7 & 52.2 & 33.8 & 25.9 & 28.8 \\
& 3 & 20.2 & 20.5 & 23.8 & 49.4 & 29.8 & 20.8 & 2.2 .8 \\
& 4 & 19.7 & 20.3 & 23.6 & 46.4 & 27.1 & 24.8 & 22.6 \\
& & & & & & & & \\
& 1 & 16.5 & 17.6 & 24.7 & 43.7 & 21.3 & 23.1 & 17.5 \\
& 2 & 17.1 & 15.9 & 21.7 & 45.3 & 27.2 & 23.1 & 22.1 \\
& 3 & 16.8 & 17.3 & 20.2 & 40.5 & 24.2 & 23.8 & 18.5 \\
& 4 & 17.0 & 18.1 & 19.1 & 41.1 & 28.4 & 23.3 & 23.1 \\
& & & & & & & & \\
& 1 & 18.03 & 20.22 & 26.56 & 48.70 & 21.84 & 26.08 & 18.91 \\
& 2 & 19.64 & 20.08 & 24.73 & 53.98 & 31.03 & 27.15 & 23.20 \\
& 3 & 16.07 & 20.65 & 20.06 & 46.79 & 27.90 & 25.95 & 21.74 \\
& 4 & 20.48 & 18.64 & 26.56 & 45.65 & 23.46 & 30.32 & 22.21
\end{tabular}


TABLE I (continued)

IAAMP NO. 3

\begin{tabular}{ccccccccc} 
Lab. & Bulb & $Z-1$ & $Z-2$ & $Z-3$ & $Z-4$ & $Z-5$ & $Z-6$ & $Z-7$ \\
\hline 1 & 1 & 14.7 & 9.8 & 15.9 & 30.1 & 15.4 & 17.3 & 14.1 \\
& 2 & 15.3 & 9.7 & 16.6 & 30.4 & 15.1 & 18.1 & 13.7 \\
& 3 & 15.1 & 9.7 & 15.6 & 29.8 & 15.4 & 18.2 & 14.8 \\
& 4 & 14.9 & 9.9 & 15.3 & 28.3 & 14.8 & 17.1 & 14.2 \\
& & & & & & & & \\
& 1 & 11.3 & 10.0 & 13.7 & 27.6 & 14.6 & 13.1 & 12.4 \\
& 2 & 11.0 & 9.8 & 13.6 & 28.0 & 14.7 & 13.0 & 11.8 \\
& 3 & 10.6 & 10.0 & 12.7 & 27.8 & 15.6 & 13.1 & 13.2 \\
& 4 & 11.5 & 10.0 & 13.9 & 27.9 & 14.7 & 13.7 & 12.8 \\
& & 12.26 & 10.73 & 14.96 & 29.62 & 15.29 & 13.93 & 12.50 \\
& 2 & 12.52 & 10.32 & 15.40 & 29.97 & 15.07 & 13.79 & 12.41 \\
& 3 & 12.17 & 10.93 & 14.36 & 29.91 & 16.26 & 14.47 & 13.73 \\
& & 11.94 & 10.53 & 14.27 & 28.71 & 15.24 & 14.19 & 13.45
\end{tabular}


TABLE 1 (continued)

LAMP NO. 4

\begin{tabular}{|c|c|c|c|c|c|c|c|c|}
\hline Lab. & Bulb & $z-1$ & $z-2$ & $z-3$ & $z-4$ & $z-5$ & $z-6$ & $z-7$ \\
\hline \multirow[t]{4}{*}{1} & 1 & 66.1 & 35.3 & 105.0 & 182.0 & 59.0 & 84.0 & 34.3 \\
\hline & 2 & 61.8 & 31.9 & 103.0 & 192.0 & 66.0 & 96.0 & 34.6 \\
\hline & 3 & 62.5 & 33.1 & 110.0 & 197.0 & 61.0 & 94.0 & 33.5 \\
\hline & 4 & 66.2 & 34.4 & 106.0 & 165.0 & 54.0 & 85.0 & 33.1 \\
\hline \multirow[t]{4}{*}{2} & 1 & 64.1 & 35.6 & 107.0 & 206.3 & 69.5 & 94.8 & 38.0 \\
\hline & 2 & 57.7 & 34.5 & 105.5 & 218.1 & 76.0 & 101.5 & 38.8 \\
\hline & 3 & 6.3 .5 & 37.8 & 114.6 & 221.7 & 73.1 & 98.3 & 37.5 \\
\hline & 4 & 68.1 & 37.4 & 109.8 & 201.1 & 69.8 & 101.1 & 40.6 \\
\hline \multirow[t]{4}{*}{3} & 1 & 59.74 & 35.05 & 107.6 & 201.0 & 63.30 & 88.00 & 32.51 \\
\hline & 2 & 62.32 & 34.95 & 104.6 & 183.2 & 58.40 & 84.20 & 32.51 \\
\hline & 3 & 61.81 & 35.53 & 111.3 & 197.6 & 60.10 & 87.40 & 32.18 \\
\hline & 4 & 63.63 & 38.37 & 110.0 & 184.6 & 58.70 & 84.20 & 34.16 \\
\hline
\end{tabular}




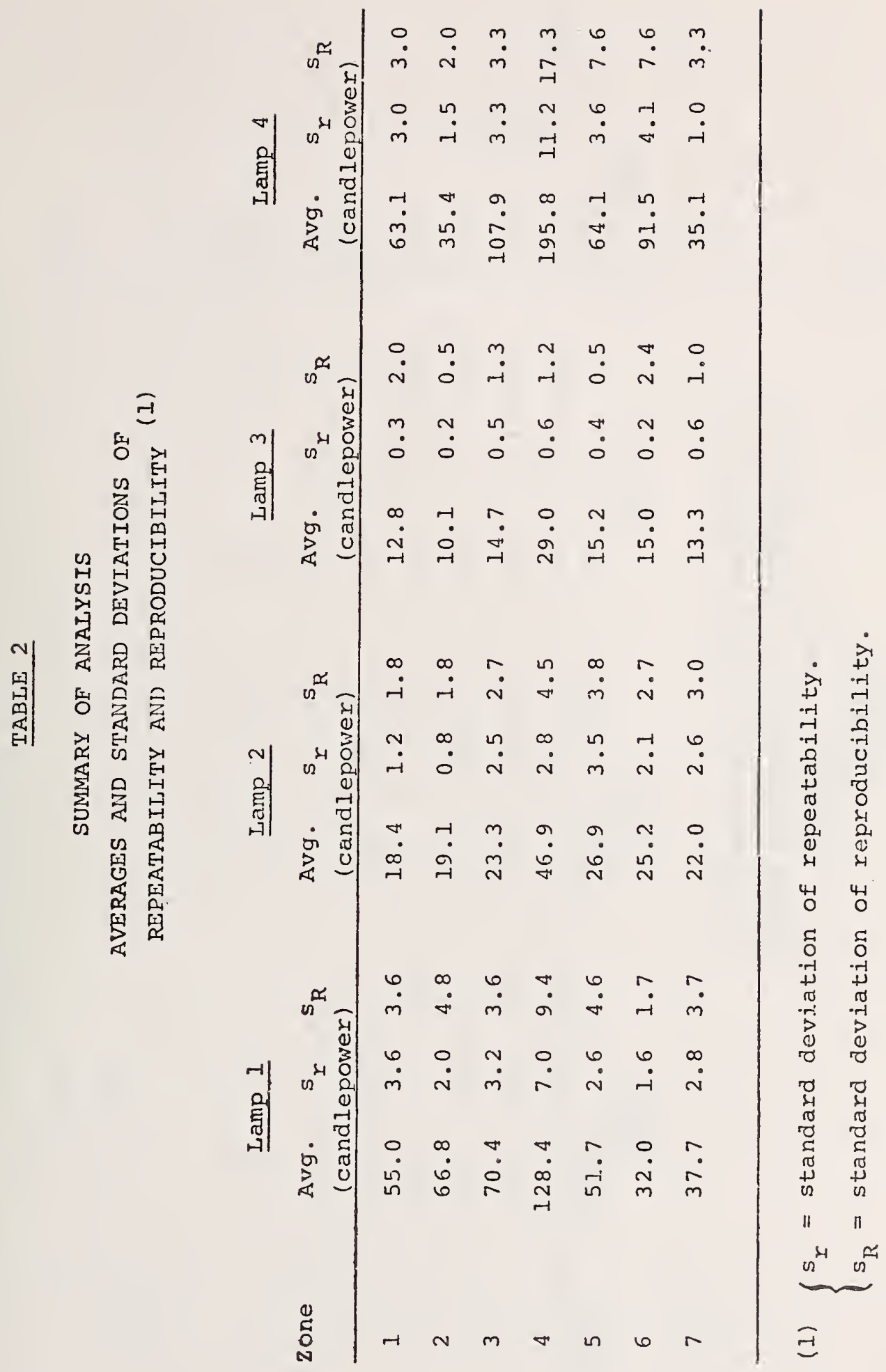




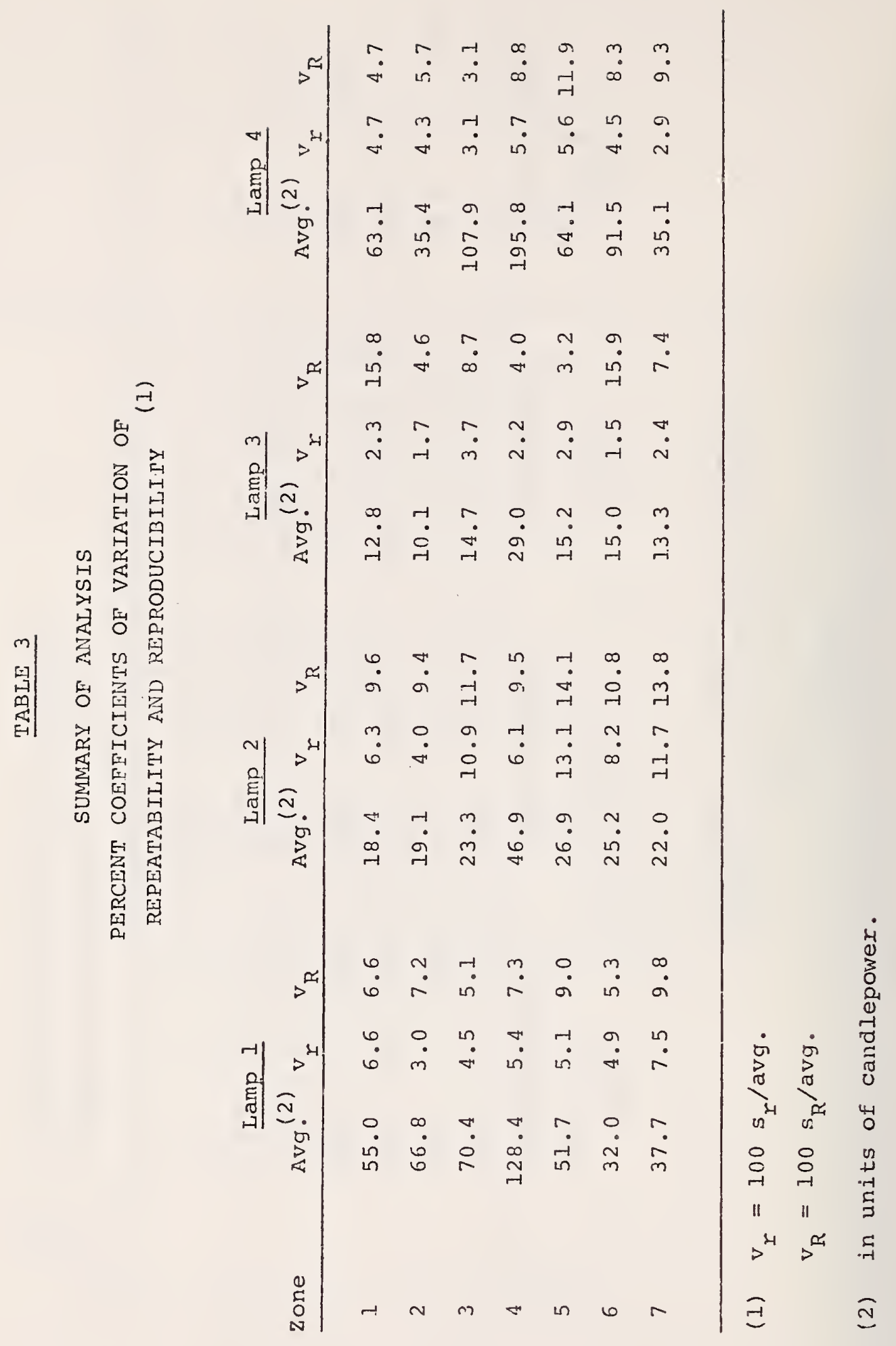




\section{TABLE 4}

\begin{tabular}{ccccc}
$\begin{array}{c}\text { Avg } \\
\circ \mathrm{CV}\end{array}$ & Lamp I & Lamp 2 & I.amp 3 & Iamp 4 \\
\hline $\bar{v}_{r}$ & 5.3 & 8.6 & 2.4 & 4.4 \\
$\bar{v}_{R}$ & 7.2 & 11.3 & 8.5 & 7.4
\end{tabular}





\begin{tabular}{|c|c|c|}
\hline $\begin{array}{l}\text { U.S. DEPT. OF COMM. } \\
\text { BIBLIOGRAPHIC DATA } \\
\text { SHEET }\end{array}$ & $\begin{array}{l}\text { 1. PUBLICATION OR REPORT NO. } \\
\text { NBS TN }-821 \\
\end{array}$ & 3. Recipient's Accession No. \\
\hline \multicolumn{2}{|l|}{ 4. TITLE AND SUBTITLE } & $\begin{array}{l}\text { 5. Publication Date } \\
\text { March } 1974\end{array}$ \\
\hline \multicolumn{2}{|c|}{$\begin{array}{l}\text { Photometric Data Variability of Automotive } \\
\text { Lighting Components }\end{array}$} & 6. Performing Organization Code \\
\hline \multicolumn{2}{|c|}{ Bert G. Simson and John Mandel } & 8. Performing Organization \\
\hline \multicolumn{2}{|c|}{ 9. PERF ORMING ORGANIZATION NAME AND ADDRESS } & 10. Project/Task/Work Unit No. \\
\hline \multicolumn{2}{|c|}{$\begin{array}{l}\text { NATIONAL BUREAU OF ST AND ARDS } \\
\text { DEPARTMENT OF COMMERCE } \\
\text { WASHINGTON, D.C. } 20234\end{array}$} & 11. Contract/Grant No. \\
\hline \multirow{2}{*}{\multicolumn{2}{|c|}{ 12. Sponsoring Organization Name and Address }} & $\begin{array}{l}\text { 13. Type of Report \& Period } \\
\text { Covered } \\
\text { Final }\end{array}$ \\
\hline & & 14. Sponsoring Agency Code \\
\hline
\end{tabular}

16. ABSTRACT ( A 200-word or less factual summary of most significant information. If document includes a significant bibliography or literature survey, mention it here.)

Four automotive lighting components were tested in three commercial testing laboratories to estimate the degree of photometric data repeatability and reproducibility. The laboratories used the photometric testing techniques required by Federal Motor Vehicle Safety standard No. 108. The precision of this test method was placed in a range of about 10 percent coefficient of variation. However, this value should be considered more as an indication of existing conditions than as à predictive parameter.

17. KEY WORDS (Alohabetical order, separated by semicolons)

Federal Motor Vehicles Safety Standards; interlaboratory test evaluation; motor vehicles; photometric testing; safety standards.

\section{AVAILABILITY STATEMENT}

X] UNLIMITED.

FOR OFFICIAL DISTRIBUTION. DO NOT RELEASE TO NTIS.
19. SECURITY CLASS (THIS REPORT)

\begin{tabular}{|l|c} 
UNCL ASSIF IED & 15 \\
\hline $\begin{array}{l}\text { 20. SECUR ITY CLASS } \\
\text { (THIS PAGE) }\end{array}$ & 22. Price \\
UNCL ASSIFIED & 60 cents \\
\hline
\end{tabular}

21. NO. OF PAGES 15 



\section{NBS TECHNICAL PUBLICATIONS}

PERIODICALS

JOURNAL OF RESEARCH reports National Burcau of Standards research and development in physics, mathematics, and chemistry. Comprehensive scientific papers give complete details of the work, including laboratory data, experimental procedures, and theoretical and mathematical analyses. Illustrated with photographs, drawings, and charts. Includes listings of other NBS papers as issued.

Published in two sections, available separately:

\section{- Physics and Chemistry (Section A)}

Papers of interest primarily to scientists working in these fields. This section covers a broad range of physical and chemical research, with major emphasis on standards of physical measurement, fundamental constants, and properties of matter. Issued six times a year. Annual subscription: Domestic, $\$ 17.00$; Foreign, $\$ 21.25$.

\section{- Mathematical Sciences (Section B)}

Studies and compilations designed mainly for the mathematician and theoretical physicist. Topics in mathematical statistics, theory of experiment design, numerical analysis, theoretical physics and chemistry, logical design and programming of computers and computer systems. Short numerical tables. Issued quarterly. Annual subscription: Domestic, $\$ 9.00$; Foreign, $\$ 11.25$.

\section{DIMENSIONS, NBS}

The best single source of information concerning the Bureau's measurement, research, developmental, cooperative, and publication activities, this monthly publication is designed for the layman and also for the industry-oriented individual whose daily work involves intimate contact with science and technology - for engineers, chemists, physicists, research managers, product-development managers, and company executives. Annual subscription: Domestic, \$6.50; Foreign, $\$ 8.25$.

\section{NONPERIODICALS}

Applied Mathematics Series. Mathematical tables, manuals, and studies.

Building Science Series. Research results, test methods, and performance criteria of building materials, components, systems, and structures.

Handbooks. Recommended codes of engineering and industrial practice (including safety codes) developed in cooperation with interested industries, professional organizations, and regulatory bodies.

Special Publications. Proceedings of NBS conferences; bibliographies, annual reports, wall charts, pamphlets, etc.

Monographs. Major contributious to the technical literature on various subjects related to the Bureau's scientific and technical activities.

National Standard Reference Data Series. NSRDS provides quantitative data on the physical and chemical properties of materials, compiled from the world's literature and critically evaluated.

Product Standards. Provide requirements for sizes, types, quality, and methods for testing various industrial products. These standards are developed cooperatively with interested Government and industry groups and provide the basis for common understanding of product characteristics for both buyers and sellers. Their use is voluntary.

Technical Notes. This series consists of communications and reports (covering both other-agency and NBS-sponsored work) of limited or transitory intercst.

Federal Information Processing Standards Publications. This series is the official publication within the Federal Government for information on standards adopted and promulgated under the Public Law 89-306, and Bureau of the Budget Circular A-86 entitled, Standardization of Data Elements and Codes in Data Systems.

Consumer Information Series. Practical information, based on NBS research and experience, covering areas of interest to the consumer. Easily understandable language and illustrations provide useful background knowledge for shopping in today's technological marketplace.

\section{BIBLIOGRAPHIC SUBSCRIPTION SERVICES}

The following current-awareness and literature-survey bibliographies are issued periodically by the Bureau:

Cryogenic Data Center Current Awareness Service (Publications and Reports of Interest in Cryogenics).

A literature survey issued weekly. Annual subscription: Domestic, $\$ 20.00$; foreign, $\$ 25.00$.

Liquefied Natural Gas. A literature survey issued quarterly. Annual subscription: $\$ 20.00$.

Superconducting Devices and Materials. A literature survey issued quarterly. Annual subscription: $\$ 20.00$. Send subscription orders and remittances for the preceding bibliographic services to the U.S. Department of Commerce, National Technical Information Service, Springfield, Va. 22151.

Electromagnetic Metrology Current Awareness Service (Abstracts of Selected Articles on Measurement Techniques and Standards of Electromagnetic Quantities from D-C to Millimeter-Wave Frequencies). Issued monthly. Annual subscription: $\$ 100.00$ (Special rates for multi-subscriptions). Send subscription order and remittance to the Electromagnetic Metrology Information Center, Electromagnetics Division, National Bureau of Standards, Boulder, Colo. 80302.

Order NBS publications (exccpt Bibliographic Subscription Services) from: Suprrintendent of Documcnts, Government Printing Office, Washington. D.C. 20402. 
U.S. DEPARTMENT OF COMMERCE

National Bureau of Standards

Washington. D.C. 20234

POSTAGE AND FEES PAID

U.S. DEPARTMENT OF COMMERCE COM-215

Penalty for Private Use, $\$ 300$

OFFICIAL BUSINESS 